\title{
Genetic Polymorphism of Cyp2a6 and Cyp2a13 Genes and Environmental Tobacco Smoke Induced Lung Cancer Risk in Indonesian Female Never Smokers
}

\author{
Noni Soeroso*(D), Rozaimah Zain-Hamid² ${ }^{1}$, Syamsul Bihar ${ }^{3}$ (D), Setia Putra $\operatorname{Tarigan}^{1}$ (D), Fannie Rizki Ananda ${ }^{3}$ (D) \\ ${ }^{1}$ Department of Pulmonology and Respiratory Medicine, Thoracic Oncology Division, Faculty of Medicine, Universitas Sumatera \\ Utara, Medan, Indonesia; ${ }^{2}$ Department of Pharmacology and Therapeutics, Faculty of Medicine, Universitas Sumatera Utara, \\ Medan, Indonesia; ${ }^{3}$ Department of Pulmonology and Respiratory Medicine, Faculty of Medicine, Universitas Sumatera Utara, \\ Medan, Indonesia
}

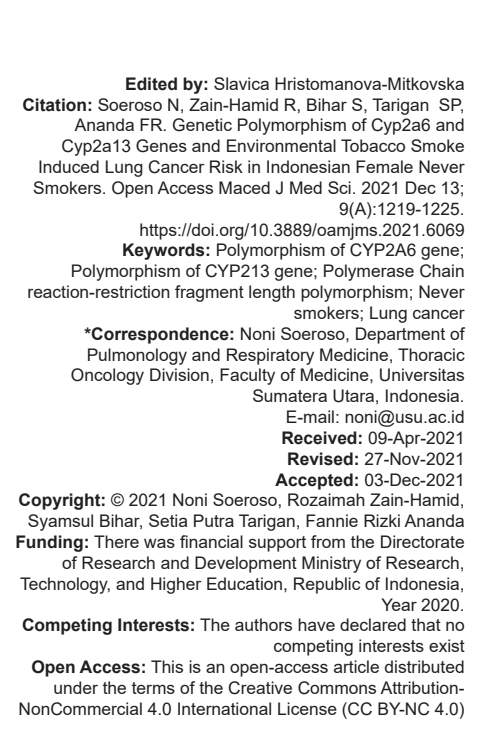

Introduction

Based on GLOBOCAN 2020 cancer registry, lung cancer becomes the third most common cancer in women, only fall behind breast and colorectal cancer [1]. Furthermore, there is a changing trend in the incidence of lung cancer from elderly to younger age. This transformation is caused by the increased incidence of the tobacco epidemic in young people aged more than 15 years old, particularly in low- to middle-income countries [2]. Nevertheless, the incidence of lung cancer in never smoker has been increased dramatically raising alarm sign that each individual has internal factors associated with lung cancer. Globally, the incidence of lung cancer in never smokers population was increased in the range $10-25 \%$ regardless of gender based on the WHO reports [3], but the absolute number was not able to be clearly delineated since no official data have been released.

Never-smoker is defined as people who smoked less than 100 cigarettes of a lifetime [4]. The prevalence of never-smoker individuals is also complicated to be estimated since the calculation is not uncommon to include passive smoker status or misreported smoking status into the calculation [5]. Lung cancer among the never-smoker population is mostly adenocarcinoma type with positive mutation of Epidermal Growth Factor Receptor but the good response in two major cancer treatment modalities is evident, chemotherapy and targeted therapy [3], [6]. The causative of never smoker lung cancer in Japan is predominantly biomass fuel exposure while in the United States radioactive exposure and indoor pollution could be the most responsible causative factors. However, lung carcinogenesis in never smoker still involved many risk factors associated with environmental tobacco smoker [4]. 
Side stream smoke contains many carcinogenic agents that have important role in DNA adducts, tumor suppressor genes, and oncogenic drivers [6]. Nicotine emerges as one of the main carcinogenic substances in cigarettes, and it was notably found in the urine sample of a child with smoker parent [7]. The presence of nicotine brought the inevitable process of lung carcinogenesis is doable in never smoker population since nicotine could the initiator of the carcinogenesis via producing some carcinogenic metabolites, including 4-(methyl nitrosamine)-1-(3-pyridyl)-1 butanone (NNK) which have a potential role in developing lung cancer [8]. NNK and N'-nitrosonornicotine (NNN) as the substance residue from the change of cotinine to 3'-Hydroxycotinine (3HC cotinine) will activate downstream signaling pathway that lead to the activation of oncogenic drivers in RAS-RAF-MAPK and P13K pathway [9]. CYP2A6, CYP2A13, and CYP2A13 involve in the nicotine metabolism [8], [10]. All of these enzymes metabolize cotinine to $3 \mathrm{HC}$ cotinine and within this process, cotinine also converted into (methylnitrosamino)-1-(3-pyridyl)-1-butanone (NNK), 4-(methylnitrosamino)-1-(3-pyridyl)-1-butanol, and N'- nitrosonornicotine (NNN) through nitrosation [8].

The polymorphism of these enzymes will undermine nicotine metabolism process that has several implications to its own metabolic rate, if polymorphism is presence in the alleles of CYP2A6*4, it could have a protective effect from developing lung cancer due to its nictonine slowly metabolism characteristic [11], [12], [13]. In addition, the CYP2A13 which is highly found in the respiratory epithelium in the upper airway has an inconsistent effect in the development of lung cancer. CYP2A13 has high activity in the metabolic activation of NNK, but the transition of 3375 cytosine to Thymin caused an amino acid substitution at the 257 sites that significantly reduced the metabolic activity of CYP2A13 and ultimately lessen the risk of lung cancer [14].

In former studies, there has been a study elaborating the correlation between polymorphism of CYP2A6 and CYP2A13 and the incidence of lung cancer in Bataknese male smokers in Indonesia [15], but there has no data about the expression of CYP2A6 and CYP2A13 in women with never smoker status. Therefore, this study aims to evaluate the correlation between polymorphism of CYP2A6 and CYP2A13 with the incidence of lung cancer among never-smoker women.

\section{Materials and Methods}

\section{Study design and participants}

This was a case-control study with purposive sampling. This study was held from May until December 2020 and was approved by the Ethics Committee of Faculty of Medicine, Universitas Sumatera
Utara, Indonesia. All participants were recruited from a few hospitals allied with the Department of Pulmonology and Respiratory Medicine including $\mathrm{H}$. Adam Malik General Hospital, Santa Elisabeth Hospital, and Universitas Sumatera Utara Hospital. Total participants were 203 subjects divided into two stages of research; first stage was CYP2A6 polymorphism consisted of 53 subjects as case studies and 50 subjects as control. The second stage was CYP2A13 polymorphism consisted of 52 subjects as case studies and 52 subjects as control.

The inclusion criteria for both case groups were women, age $>25$ years old, diagnosed with lung cancer based on clinical and radiological examination and confirmed by cytology and histopathology investigation from bronchoscopy and Trans-thoracal Lung Biopsy and Trans-Thoracal Needle Aspiration. Meanwhile, the control groups were recruited from the wife of patients in lung cancer and the employees in the hospital where the study was conducted who was matched to the case group according to sex, age, and smoking history. Before attending the study, all the participants were informed about the study protocol and signed the informed consent. Exclusion criteria in this study were sample which was not successfully extracted and damaged at the time polymerase chain reaction (PCR) examination.

\section{DNA extraction}

A peripheral blood sample was obtained by venopuncture about $2 \mathrm{~mL}$, placed in a sterile tube contained EDTA, and stored at $-80^{\circ} \mathrm{C}$. DNA was extracted using Isolation Kit DNA Puregene (Pro Mega). Genotypes were analyzed using PCR-based methods.

\section{Genotyping CYP2A6}

The genotypes of CYP2A6 * 1A, CYP2A6 * 1B, CYP2A6 * 4A were analyzed by PCR-restriction fragmentlength polymorphism(RFLP). The primerused were 2Aex7F (5'-GRCCAAGATGCCCTACATG-3') 15 and 2A6R2 (5'-AAAATGGGATGATGGGGG) Sample C-Gen (C) $0.5 \mathrm{lg}$ ) added with PCR mixtures (25 II) consisting of 1 PCR buffer; $1 \times$ PCR buffer [67 $\mathrm{mM}$ Tris- $\mathrm{HCl}$ buffer $(\mathrm{pH} 8.8), 16.6 \mathrm{mM}\left(\mathrm{NH}_{4}\right)_{2} \mathrm{SO}_{4}$, $0.45 \%$ Triton $\mathrm{X}-100,0.02 \%$ gelatin], $1.5 \mathrm{mM} \mathrm{MgCl}_{2}$ $0.4 \mu \mathrm{M}$ of each primer, $250 \mu \mathrm{M}$ dNTPs, and $1 \mathrm{U}$ of Taq DNA polymerase. After an initial denaturation at $95^{\circ} \mathrm{C}$ for $1 \mathrm{~min}$, amplification was performed by denaturation at $95^{\circ} \mathrm{C}$ for $15 \mathrm{~s}$, annealing at $60^{\circ} \mathrm{C}$ for $20 \mathrm{~s}$, and extension at $72^{\circ} \mathrm{C}$ for 3 min for 35 cycles, followed by a final extension at $72^{\circ} \mathrm{C}$ for $7 \mathrm{~min}$. The PCR product was double-digested with Eco81I and Accll restriction enzymes. The digestion patterns were determined by electrophoresis in a $1.5 \%$ agarose gel [16] 


\section{Genotyping CYP2A13}

PCR with (RFLP-PCR) was performed to identify the genetic polymorphism of CYP2A13. Exon 5 of the CYP2A13 gene was amplified using a forward primer 5'-CCTGGACAGATGCCTTTAACTCCG-3' paired with a reverse primer 5'-TGGCTTTGCACCTGCCTGCACT-3'. PCR amplification was performed in a Bio-Rad DNA Model T-100 Thermal Cycler in a total volume of $25 \mu$ containing approximately $200 \mathrm{ng}$ of genomic DNA, 2.5 $\mu \mathrm{l} \times$ PCR buffer $2 \mathrm{mmol} / \mathrm{l} \mathrm{MgCl} 2,0.2 \mathrm{mmol} / \mathrm{l}$ of each dNTP, $0.28 \mu \mathrm{mol} / \mathrm{l}$ of each primer, and $2 \mathrm{U}$ of Taq DNA polymerase. The PCR conditions involved an initial denaturation at $95^{\circ} \mathrm{C}$ for $3 \mathrm{~min}$, followed by 35 cycles of denaturation at $95^{\circ} \mathrm{C}$ for $30 \mathrm{~s}$, annealing at $63^{\circ} \mathrm{C}$ for $45 \mathrm{~s}$, and extension at $72^{\circ} \mathrm{C}$ for $30 \mathrm{~s}$, with a final extension at $72^{\circ} \mathrm{C}$ for $5 \mathrm{~min}$. After amplification, the PCR products (332 bp) were digested with $\mathrm{Hhal}$ restriction. Endonuclease at $37^{\circ} \mathrm{C}$ for at least $4 \mathrm{~h}$. Digested products were analyzed by electrophoresis on a $2 \%$ agarose gel in the presence of ethidium bromide.

\section{Data analysis}

All data were analyzed using Epi Info-7 software. Chi-square was used to assess significant differences in demographic characteristics factor. Logistic regression was undergone to assess the correlation between polymorphism of CYP2A6 and CYP2A13 with the incidence of lung cancer. By this statistical test, the risk of each allele to develop lung cancer could be obtained. A p $<0.05$ was considered statistically significant. Genotype frequency deviation was obtained from Hardy-Equiblirium pada CYP2A6 dan CYP2A13.

\section{Results}

This study involved 203 female subjects divided into two stages of study with 101 subjects were performed CYP2A6 polymorphism and 102 subjects for CYP2A13 polymorphism.

From Table 1, we can conclude that the majority of the study was in the 50-59 years old age group with adenocarcinoma. Because the majority of subjects were household wife, the source of smoking exposure was at home with the duration of exposure was more than 10 years. Mostly biomass exposure was acquired from mosquito repellant, chalk, and firewood exposure.

Before analyzing the association between CYP2A6 and CYP2A13 with lung cancer, we first performed the Hardy Weinberg analysis, in which all alleles are in equilibirium state, both in lung cancer and healthy control groups ( $p>0.05)$.

\section{Regression logistic}

The distribution of genotypes in Polymorphism of CYP2A6 and CYP2A13 was seen in Table 2. Genotype *1B/*1B was discovered as the highest frequencies compare with the others in both groups of CYP2A6 while genotype CC has the highest frequencies in both groups of CYP2A13. There was a significant correlation between genotypes of CYP2A13 and the incidence of lung cancer $(p<0.05)$. People with the genotype CT have 2.7 higher risks for developing lung cancer compared with genotype CC. However, there was no significant correlation between the genotypes of CYP2A6 with the incidence of lung cancer. After multivariate analysis using regression logistic test, both people with the genotype * $1 \mathrm{~A} /{ }^{*} 1 \mathrm{~B}$ and ${ }^{*} 1 \mathrm{~B} /{ }^{*} 1 \mathrm{~B}$ have a lower risk (0.64 times) for developing lung cancer compared with genotype ${ }^{*} 1 \mathrm{~A} /{ }^{*} 1 \mathrm{~A}$ with a wide range of confidence interval.

\section{Regression logistic test}

Table 3 showed the distribution of alleles in both case and control groups of CYP2A6 and CYP2A13. There was no significant correlation between alleles in CYP2A6 and CYP2A13 and the incidence of lung cancer. Allele ${ }^{*} 1 \mathrm{~B}$ was the most common allele in CYP2A6 and tend to have 0.75 times for developing lung cancer; however, it has a wide range of confidence interval (0.42-1.33). On the other side, allele $C$ has more frequencies and has a 0.62 times risk for developing lung cancer compared with allele $T$ with a wide range of confidence intervals (0.73-3.52).

\section{Genotyping results CYP2A6 and CYP2A13}

From the two pictures above, genotype polymorphisms of CYP2A6 showed alleles frequencies of ${ }^{*} 1 \mathrm{~A}$ was 86 subjects, allele ${ }^{*} 1 \mathrm{~B}$ was 110 subjects, and ${ }^{*} 4 \mathrm{~A}$ allele was 2 subjects. While in genotyping polymorphisms of CYP2A 13 showed alleles frequencies of $C$ was 178 subjects and allele $T$ was 30 subjects. Further Genotyping results were shown in Figure 1 and Figure 2.

\section{Discussion}

In the increased incidence of lung cancer in never smokers, many risk factors were analyzed epidemiologically and biologically. There are a few risk factors correlated with the incidence of lung cancer in never smoker, including age, environmental tobacco smoke, air pollution including indoor (household fumes) and outdoor (vehicle emission), inherited genetic susceptibility, occupational and environmental exposure to carcinogens, imbalance of hormonal 
Table 1: Distribution characteristics by study stage and case-control study

\begin{tabular}{|c|c|c|c|c|c|c|c|c|c|c|}
\hline \multirow[t]{3}{*}{ Variable } & \multicolumn{5}{|c|}{ CYP2A6 } & \multicolumn{4}{|c|}{ CYP2A13 } & \multirow[t]{3}{*}{$p$-value } \\
\hline & \multicolumn{2}{|c|}{ Case } & \multicolumn{2}{|c|}{ Control } & \multirow[t]{2}{*}{$\mathrm{p}$-value } & \multicolumn{2}{|c|}{ Case } & \multicolumn{2}{|c|}{ Control } & \\
\hline & $\mathrm{n}$ & $\%$ & $\mathrm{n}$ & $\%$ & & $\mathrm{n}$ & $\%$ & $\mathrm{n}$ & $\%$ & \\
\hline \multicolumn{11}{|l|}{ Age } \\
\hline$<40$ years old & 0 & 0.0 & 3 & 6.5 & \multirow{5}{*}{$<0.01$} & 0 & 0.0 & 3 & 5.8 & \\
\hline $40-49$ years old & 12 & 22.6 & 28 & 60.9 & & 10 & 19.2 & 33 & 63.5 & \\
\hline $50-59$ years old & 20 & 37.7 & 15 & 32.6 & & 19 & 36.5 & 16 & 30.8 & $<0.01$ \\
\hline $60-69$ years old & 17 & 32.1 & 0 & 0.0 & & 18 & 34.6 & 0 & 0.0 & \\
\hline$\geq 70$ years old & 4 & 7.5 & 0 & 0.0 & & 5 & 9.6 & 0 & 0.0 & \\
\hline \multicolumn{11}{|l|}{ Occupation } \\
\hline Cleaning service & 0 & 0.0 & 7 & 15.2 & \multirow{7}{*}{$<0.01$} & 0 & 0.0 & 9 & 17.3 & \multirow{7}{*}{$<0.01$} \\
\hline Teachers & 2 & 3.9 & 6 & 13.0 & & 3 & 5.8 & 6 & 11.5 & \\
\hline Household wife & 40 & 75.5 & 15 & 32.6 & & 37 & 71.2 & 14 & 26.9 & \\
\hline Nurse & 0 & 0.0 & 12 & 26.1 & & 0 & 0.0 & 16 & 30.8 & \\
\hline Farmer & 1 & 1.9 & 0 & 0.0 & & 1 & 1.9 & 0 & 0.0 & \\
\hline Office women & 3 & 5.7 & 4 & 8.7 & & 4 & 7.7 & 5 & 9.6 & \\
\hline Businesswomen & 7 & 13.2 & 2 & 4.3 & & 7 & 13.5 & 2 & 3.8 & \\
\hline \multicolumn{11}{|l|}{ Passive smoker } \\
\hline In house & 30 & 56.6 & 30 & 65.2 & \multirow[t]{2}{*}{0.47} & 32 & 61.5 & 34 & 65.4 & \multirow[t]{2}{*}{0.28} \\
\hline Work & 7 & 13.2 & 4 & 8.7 & & 6 & 11.5 & 3 & 5.8 & \\
\hline \multicolumn{11}{|l|}{ Histopathology } \\
\hline Adenocarcinoma & 51 & 96.2 & & 0.0 & \multirow[t]{2}{*}{ N/A } & 50 & 96.2 & & 0.0 & \multirow[t]{2}{*}{$\mathrm{N} / \mathrm{A}$} \\
\hline Squamous Cell Carcinoma & 2 & 3.8 & & 0.0 & & 2 & 3.8 & & 0.0 & \\
\hline \multirow{2}{*}{\multicolumn{11}{|c|}{ Duration of smoking exposure }} \\
\hline$<10$ years & 11 & 20.8 & 3 & 6.5 & & & & & & \multirow[b]{2}{*}{0.03} \\
\hline$\geq 10$ years & 20 & 37.7 & 29 & 63.0 & 0.05 & 10 & 19.2 & 31 & 59.6 & \\
\hline \multicolumn{11}{|l|}{ Biomass exposure } \\
\hline Mosquito repellant & 11 & 20.8 & 4 & 8.7 & & 12 & 23.1 & 7 & 13.5 & \\
\hline Chalk exposure & 9 & 17.0 & 14 & 30.4 & & 11 & 21.2 & 17 & 32.7 & \\
\hline Pesticide & 4 & 7.5 & 3 & 6.5 & 0.37 & 5 & 9.6 & 4 & 7.7 & 0.37 \\
\hline Garbage fumes & 6 & 11.3 & 9 & 19.6 & & 7 & 13.5 & 9 & 17.3 & \\
\hline Firewood & 10 & 18.9 & 6 & 13.0 & & 11 & 21.2 & 7 & 13.5 & \\
\hline Race & & & & & & & & & & \\
\hline Batak & 32 & 57.1 & 33 & 76.0 & & 30 & 57.7 & 38 & 73.1 & \\
\hline Jawa & 19 & 33.9 & 9 & 18.0 & & 18 & 34.6 & 11 & 21.2 & \\
\hline Melayu & 2 & 3.6 & 2 & 4 & & 1 & 1.9 & 2 & 3.8 & \\
\hline Chinese & 2 & 3.6 & 0 & 0 & 0.108 & 2 & 3.8 & 0 & 0 & 0.049 \\
\hline Aceh & 1 & 1.8 & 0 & 0 & & 1 & 1.9 & 0 & 0 & \\
\hline Minang & 0 & 0 & 1 & 2 & & 0 & 0 & 1 & 1.9 & \\
\hline Total & 53 & 100.0 & 46 & 100.0 & & 52 & 100.0 & 52 & 100.0 & \\
\hline
\end{tabular}

factors, pre-existing of lung disease, dietary factors, and oncogenic virus particularly HPV infections [3], [5], [17], [18], [19].

Biomass fuel is the use biologic materials both animal and plants origin, including wood, crop residues, dung, and charcoal [20]. Although there was a shift of using this traditional fuel to electricity and liquid petroleum gas, people in rural areas in South East Asia, particularly Indonesia still use them for cooking and heating [21]. Polyaromatic Hydrocarbon (PAH) and small particulate matter have key component of biomass fuel related to lung cancer. Small particulate matter induced prolonged inflammation that will increase the Reactive Oxygen Species and directly cause the

Table 2: Genotype frequencies of CYP2A6 and CYP2A13 among case and control and their association with lung cancer

\begin{tabular}{|c|c|c|c|c|c|c|c|}
\hline \multirow[t]{2}{*}{ Genotyping } & \multicolumn{2}{|c|}{ Lung cancer } & \multicolumn{2}{|c|}{ Healthy control } & \multirow[t]{2}{*}{$p$-value } & \multirow[t]{2}{*}{ OR } & \multirow[t]{2}{*}{ Confidence interval } \\
\hline & $\mathrm{n}$ & $\%$ & $\mathrm{n}$ & $\%$ & & & \\
\hline \multicolumn{8}{|l|}{ CYP2A6 } \\
\hline$* 1 \mathrm{~A}^{*} 1 \mathrm{~A}$ & 17 & 32.1 & 11 & 23.9 & 0.61 & 1 & 1 \\
\hline${ }^{*} 1 \mathrm{~A} /{ }^{*} 1 \mathrm{~B}$ & 15 & 28.3 & 15 & 32.6 & & 0.64 & $0.22-1.83$ \\
\hline${ }^{*} 1 \mathrm{~B} /{ }^{*} 1 \mathrm{~B}$ & 20 & 37.7 & 20 & 43.5 & & 064 & $0.24-1.72$ \\
\hline${ }^{*} 4 \mathrm{~A} /{ }^{*} 4 \mathrm{~A}$ & 1 & 1.9 & 0 & 0.0 & & N/A & N/A \\
\hline \multicolumn{8}{|l|}{ CYP2A13 } \\
\hline CC & 34 & 65.4 & 42 & 80.8 & $0.035^{\star}$ & 1 & 1 \\
\hline СT & 18 & 34.6 & 8 & 15.4 & & 2.7 & $1.07-7.16$ \\
\hline TT & 0 & 0.0 & 2 & 3.8 & & N/A & $\mathrm{N} / \mathrm{A}$ \\
\hline
\end{tabular}

cell destruction. In the other side, PAH is essential substance which played important role in DNA adduct and correlated with the expression of some tumor suppressor gene such as p53 and oncogenic drivers such as KRAS and HRAS [21]. However, the definite time for the exposure of biomass exposure in lung cancer incidence remains unknown. In this study, the highest prevalence of biomass exposure was firewood and mosquito repellant. This difference etiology may vary because of the social and geographical aspects wherein developing country such as Indonesia, women helped the household by working as farmers who used pesticide, used firewood as the cooking fuel, and used mosquito repellant dust because of the geographical location where the population of mosquito is high.

Table 3: Allele frequencies of CYP2A6 and CYP2A13 among case and control and their association with lung cancer

\begin{tabular}{|c|c|c|c|c|c|c|c|}
\hline \multirow[t]{2}{*}{ Alleles } & \multicolumn{2}{|c|}{ Lung cancer } & \multicolumn{2}{|c|}{ Healthy control } & \multirow[t]{2}{*}{$p$-value } & \multirow[t]{2}{*}{ OR } & \multirow{2}{*}{$\begin{array}{l}\text { Confidence } \\
\text { interval }\end{array}$} \\
\hline & $\mathrm{n}$ & $\%$ & $\mathrm{n}$ & $\%$ & & & \\
\hline \multicolumn{8}{|l|}{ CYP2A6 } \\
\hline CYP2A6*1A & 49 & 46.2 & 37 & 40.2 & 0.25 & 1 & 1 \\
\hline CYP2A6*1B & 55 & 51.9 & 55 & 59.8 & & 0.75 & $0.42-1.33$ \\
\hline CYP2A6*4A & 2 & 1.9 & 0 & 0.0 & & N/A & $N / A$ \\
\hline \multicolumn{8}{|l|}{ CYP2A13 } \\
\hline C & 86 & 82.7 & 92 & 88.5 & 0.23 & 1 & 1 \\
\hline $\mathrm{T}$ & 18 & 17.3 & 12 & 11.5 & & 1.6 & $0.73-3.52$ \\
\hline
\end{tabular}

While smoking is the major dominant factor contributes to the development of lung cancer [1], the incidence of lung cancer in never smoker populations, particularly women is increasing with significant geographic variations [22]. Recent articles also showed that environmental tobacco smoker was one of the major risk factors in developing lung cancer in women never smokers [3]. Indirectly, it showed that both active and passive smoker has the risk for developing lung cancer. In the European never-smoker population, women tend to have lung cancer risk more than the male population because of some different biological aspects including hormonal, oncogenic drivers expression, and mutation 


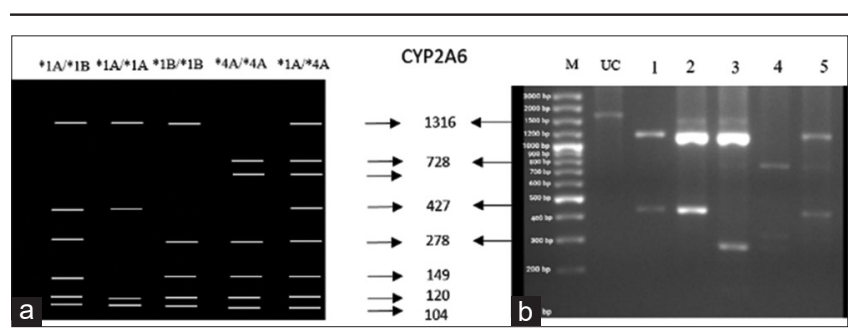

Figure 1: Genotyping CYP2A6 *1A, CYP2A6 *1B and CYP2A6 *4A. (a) Schematic polymerase chain reaction (PCR-RFLP) patterns for different CYP2A6 alleles. CYP2A6*1A yields 1,316, 427, 120, and 104 bp fragments, CYP2A6*1B yields 1,316, 278, 149, 120, and 104 bp fragments, CYP2A6*4A yields $728,587,278,149,120$, and 104 bp fragments, CYP2A6*4D and CYP2A6*1F yield 728, 587, 427, 120 , and $104 \mathrm{bp}$, and CYP2A6*1G yields 620, 587, 427, 120, 108, and 104 bp fragments. (b) Representative photographic of PCR-RFLP pattern for differentiate CYP2A6 allele line M: Marker (3000bp), UC: Uncut, line 1: ${ }^{*} 1 A /{ }^{*} 1 B$, line $2:{ }^{*} 1 A /{ }^{*} 1 A$, line $3:{ }^{*} 1 B /{ }^{*} 1 B$, line $4:{ }^{*} 4 A /{ }^{*} 4 A$, lane 5: *1A/*4A

of some epigenetic factors, and tumor suppressor gene [23], [24].

In Asian population, although lung cancer incidence still abides with the global trends, never smoker in women group are proved otherwise. The proportion of women never smoker had higher occurrence for diagnosed of lung cancer compared to other areas in western countries. Polymorphism of CYP2A6 and CYP2A13 could be responsible for the condition, since this allele polymorphism supporting nicotine metabolism was more prevalent in Asian population, such as the highest prevalence of alleles *1B in Asian Population [12], [25], [26]. The activity of nicotine metabolism enzymes may be one of the factors that may contribute to these inconsistent results. According to recent study, alleles *4, *9, *12 have known as slow metabolizer, while alleles *1 known as rapid metabolizer [27]. Both active smokers and environmental tobacco smokers showed the presents of cotinine as a nicotine metabolite secreted in the urine, although it varied among active and environmental tobacco smokers [28].

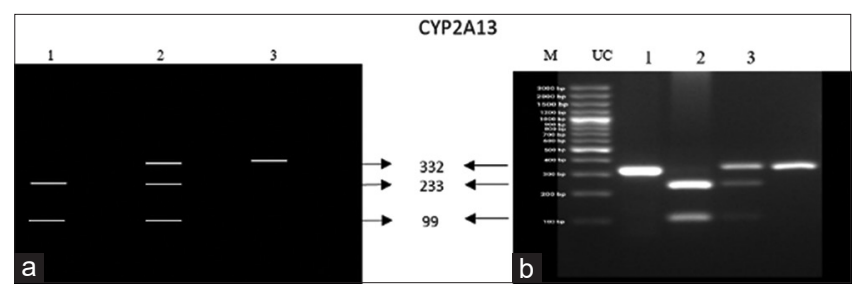

Figure 2: Genotyping of CYP2A13 (a) Schematic PCR-RFLP patterns of CYP2A13, line 1 : wild type genotype (233,99bp), line 2 : heterozygous genotype $(332,233,99 \mathrm{bp})$, line 3 : mutant genotype (332bp). (b) Photographic representation of PCR-RFLP patterns of CYP2A13 line M: Maker, lane UC: Uncut, line 1: CC, line 2: CT, and line 3: $T T$

The polymorphisms of CYP2A6 and CYP2A13 as major enzymes in nicotine metabolism played important role in smoking status and developing lung cancer in active and environmental tobacco smokers [14], [29], [30]. In recent studies, male-bataknese smoker showed that allele *1B was the most common allele found with the highest rate of nicotine metabolism, although it was not significantly associated with the incidence of lung cancer [15], [31]. As polymorphism of CYP2A6 has wide variants, allele *4 was known as "loss function" enzymes in nicotine metabolism. People with CYP2A6*4 tend to smoke less intensively and having less risk of lung cancer [11], [12]. In this study, we found only two participants showed the expressions of CYP2A6*4 in the case group, and there were no expressions of CYP2A6*4 in the control group, so the risk analysis compares to the wild type of CYP2A6 (CYP2A6*1) could not be performed. Meanwhile, the most common allele was * $1 \mathrm{~B}$, and this is in line with a few multivariate studies which showed that allele *1 was the most common in the population and related to high consumption of cigarettes and a higher risk of lung cancer compared with allele *4 [12], [32].

Mainly expressed in respiratory epithelium and becomes one of the main enzymes in nicotine metabolism, CYP2A13 also metabolizes Aflatoxin B1 that is a carcinogenic substance that causes cytotoxicity effect, inflammation, and DNA damage. All these processes lead to form lung carcinogenesis [33]. Converse with CYP2A6, we found a significant association between CYP2A13 genotype CT and allele $\mathrm{T}$ and the higher risk for developing lung cancer until 2.7 times and 1.6 times. This is different from the Timofeeva study that showed that genotype CT/ TT have a lower risk for developing lung cancer in the female population both in never/light smoker and strong smoker [34]. The same results were also found in Wang's study that showed a significant reduction of lung cancer risk in genotype CT+TT in the light smoker population, although it was not significant in never and a heavy smoker [14]. According to Zhang et al., the substitution of the $\mathrm{C}$ to $\mathrm{T}$ allele decreases the metabolic activity of nicotine and also serves as some protection against xenobiotic toxicity in the respiratory tract [35]. These inconsistent results might be caused by the biologic component of CYP2A13 Arg257Cys which contradicts each other. Geographic factor analysis with advanced molecular characteristics of CYP2A13 and a larger scale of study is needed to assess the impact of polymorphism of CYP2A13 and the incidence of lung cancer.

This study has several limitations including the minimal sample size and limitation of the PCR method. RT-PCR with sequencing analysis may further be carried out to analyze whether the polymorphism associated with the mutation type of CYP2A6 and CYP2A13 in a certain geographic area, particularly Indonesia.

This study provided data about the risk factor of lung cancer in women never smokers in North Sumatera, Indonesia, and was the first study to analyze the main enzyme of nicotine metabolism in neversmoker patients in Southeast Asia. However, further comprehensive and broads discussions are needed to assess the biological impact of polymorphism of 
CYP2A6 and CYP2A13 in the lung carcinogenesis in never-smoker population.

\section{Conclusions}

There was a significant correlation between polymorphism CYP213 with the incidence of lung cancer among female lung cancer never smoker. However, the results show no significant relationship between CYP2A6 genetic polymorphism and lung cancer incidence.

\section{Acknowledgment}

The authors grateful for the contribution of $\mathrm{H}$. Adam Malik General Hospital, Santa Elisabeth Hospital, and Universitas Sumatera Utara Hospital which had known as hospital referral for oncology patients and the entire staff for the opportunities given during the study. The author also expressed his appreciation to the Integrated Laboratory Faculty of Medicine, University of North Sumatra and the Health Research Ethics Committee of the University of North Sumatra for giving permission.

\section{References}

1. Sung H, Ferlay J, Siegel RL, Laversanne M, Soerjomataram I, Jemal A, et al. Global cancer statistics 2020: GLOBOCAN estimates of incidence and mortality worldwide for 36 cancers in 185 countries. CA Cancer J Clin. 2021;71(3):209-49. https://doi. org/10.3322/caac. 21660

PMid:33538338

2. WHO. WHO Global Report on Trends in Prevalence of Tobacco Smoking 2000-2025. $2^{\text {nd }}$ ed. Geneva: WHO; 2018. Available from: http://www.apps.who.int/bookorders [Last accessed on 2021 Feb 15].

3. Couraud S, Zalcman G, Milleron B, Morin F, Souquet PJ. Lung cancer in never smokers-a review. Eur $\mathrm{J}$ Cancer. 2012;48(9):1299-311. https://doi.org/10.1016/j. ejca.2012.03.007

PMid:22464348

4. Samet JM, Avila-Tang E, Boffetta P, Hannan LM, OlivoMarston S, Thun MJ, et al. Lung cancer in never smokers: Clinical epidemiology and environmental risk factors. Clin Cancer Res. 2009;15(18):5626-45. https://doi.org/10.1158/1078-0432. CCR-09-0376 PMid:19755391

5. Bhopal A, Peake MD, Gilligan D, Cosford P. Lung cancer in neversmokers: A hidden disease. J R Soc Med. 2019;112(7):269-71. https://doi.org/10.1177/0141076819843654

\section{PMid:31022354}

6. Okazaki I, Ishikawa S, Ando W, Sohara Y. Lung adenocarcinoma in never smokers: Problems of primary prevention from aspects of susceptible genes and carcinogens. Anticancer Res. 2016;36(12):6207-24. https://doi.org/10.21873/anticanres.11215 PMid:27919939

7. Thomas JL, Guo H, Carmella SG, Balbo S, Han S, Davis A, et al Metabolites of a tobacco-specific lung carcinogen in children exposed to secondhand or thirdhand tobacco smoke in their homes. Cancer Epidemiol Biomarkers Prev. 2011;20(6):1213-21. PMid:21467230

8. Warren G, Singh A. Nicotine and lung cancer. J Carcinog 2013;12:1. https://doi.org/10.4103/1477-3163.106680 PMid:23599683

9. Hecht SS. Lung carcinogenesis by tobacco smoke. Int J Cancer. 2012;131(12):2724-32. https://doi.org/10.1002/ijc.27816 PMid:22945513

10. Benowitz NL, Hukkanen J, Jacob $P 3^{\text {rd }}$. Nicotine chemistry, metabolism, kinetics and biomarkers. Handb Exp Pharmacol. 2009;(192):29-60. https://doi.org/10.1007/978-3-540-69248-5_2 PMid:19184645

11. Johani FH, Majid MS, Azme MH, Nawi AM. Cytochrome P450 2A6 whole-gene deletion (CYP2A6*4) polymorphism reduces risk of lung cancer: A meta-analysis. Tob Induc Dis. 2020;18:50. https://doi.org/10.18332/tid/122465 PMid:32547353

12. Wang L, Zang W, Liu J, Xie D, Ji W, Pan Y, et al. Association of CYP2A6*4 with susceptibility of lung cancer: A meta-analysis. PLoS One. 2013;8(4):e59556. https://doi.org/10.1371/journal. pone.0059556

PMid:23585826

13. Ariyoshi $\mathrm{N}$, Miyamoto $\mathrm{M}$, Umetsu $\mathrm{Y}$, Kunitoh $\mathrm{H}$, Dosaka-Akita $\mathrm{H}$, Sawamura $Y$, et al. Genetic polymorphism of CYP2A6 gene and tobacco-induced lung cancer risk in male smokers. Cancer Epidemiol Biomarkers Prev. 2002;11(9):890-4 PMid:12223434

14. Wang H, Tan W, Hao B, Miao X, Zhou G, He F, et al. Substantial reduction in risk of lung adenocarcinoma associated with genetic polymorphism in CYP2A13, the most active cytochrome P450 for the metabolic activation of tobacco-specific carcinogen NNK. Cancer Res. 2003;63(22):8057-61.

PMid:14633739

15. Soeroso NN, Zain-Hamid R, Sinaga BY, Sadewa AH, Syafiuddin T, Syahruddin E, et al. Genetic polymorphism of CYP2A6 and its relationship with nicotine metabolism in male bataknese smokers suffered from lung cancer in Indonesia. Open Access Maced J Med Sci. 2018;6(7):1199-205. https:// doi.org/10.3889/oamjms.2018.259 PMid:30087722

16. Nakajima M, Yoshida R, Fukami T, McLeod HL, Yokoi T. Novel human CYP2A6 alleles confound gene deletion analysis. FEBS Lett. 2004;569(1-3):75-81. https://doi.org/10.1016/j. febslet.2004.05.053 PMid: 15225612

17. Couraud S, Souquet PJ, Paris C, Dô P, Doubre H, Pichon E, et al BioCAST/IFCT-1002: Epidemiological and molecular features of lung cancer in never-smokers. Eur Respir J. 2015;45(5):1403-14. https://doi.org/10.1183/09031936.00097214 PMid:25657019

18. Sun S, Schiller JH, Gazdar AF. Lung cancer in never smokers-a different disease. Nat Rev Cancer. 2007;7(10):778-90. https:// doi.org/10.1038/nrc2190 PMid:17882278

19. McCarthy WJ, Meza R, Jeon J, Moolgavkar SH. Chapter 6: 
Lung cancer in never smokers: Epidemiology and risk prediction models. Risk Anal. 2012;32 Suppl 1:S69-84. https://doi. org/10.1111/j.1539-6924.2012.01768.x

PMid:22882894

20. Torres-Duque C, Maldonado D, Pérez-Padilla R, Ezzati M, Viegi G, Forum of International Respiratory Studies (FIRS) Task Force on Health Effects of Biomass Exposure. Biomass fuels and respiratory diseases: A review of the evidence. Proc Am Thorac Soc. 2008;5(5):577-90. https://doi.org/10.1513/ pats.200707-100RP

PMid: 18625750

21. Lim WY, Seow A. Biomass fuels and lung cancer. Respirology. 2012;17(1):20-31. https://doi. org/10.1111/j.1440-1843.2011.02088.x

PMid:22008241

22. Park B, Kim Y, Lee J, Lee N, Jang SH. Sex difference and smoking effect of lung cancer incidence in asian population. Cancers (Basel). 2020;13(1):113. https://doi.org/10.3390/ cancers 13010113

PMid:33396462

23. Gasperino J. Gender is a risk factor for lung cancer. Med Hypotheses. 2011;76(3):328-31. https://doi.org/10.1016/j. mehy.2010.10.030

PMid:21106301

24. Freedman ND, Leitzmann MF, Hollenbeck AR, Schatzkin A Abnet CC. Cigarette smoking and subsequent risk of lung cancer in men and women: Analysis of a prospective cohort study. Lancet Oncol. 2008;9(7):649-56. https://doi.org/10.1016/ S1470-2045(08)70154-2

PMid:18556244

25. Liu T, Xie CB, Ma WJ, Chen WQ. Association between CYP2A6 genetic polymorphisms and lung cancer: A meta-analysis of case-control studies. Environ Mol Mutagen. 2013;54(2):133-40. https://doi.org/10.1002/em.21751

PMid:23203414

26. Park SL, Murphy SE, Wilkens LR, Stram DO, Hecht SS, Le Marchand L. Association of CYP2A6 activity with lung cancer incidence in smokers: The multiethnic cohort study. PLoS One. 2017;12(5):e0178435. https://doi.org/10.1371/journal. pone. 0178435

PMid:28542511

27. Benowitz NL, Swan GE, Jacob P $3^{\text {rd }}$, Lessov-Schlaggar CN,
TyndaleRF.CYP2A6genotypeandthemetabolismanddisposition kinetics of nicotine. Clin Pharmacol Ther. 2006;80(5):457-67. https://doi.org/10.1016/j.clpt.2006.08.011

PMid: 17112802

28. Sepkovic DW, Haley NJ. Metabolism of Nicotine in Smokers and Nonsmokers. Boston, MA: Springer; 1987. p. 375-88. https:// doi.org/10.1007/978-1-4613-1911-5_24

29. Kiyohara C, Takayama K, Nakanishi Y. CYP2A13, CYP2A6, and the risk of lung adenocarcinoma in a Japanese population. $J$ Health Sci. 2005;51(6):658-66. https://doi.org/10.1248/ jhs. 51.658

30. Rossini A, de Almeida Simão T, Albano RM, Pinto LF. CYP2A6 polymorphisms and risk for tobacco-related cancers. Pharmacogenomics. 2008;9(11):1737-52. https://doi. org/10.2217/14622416.9.11.1737

PMid: 19018727

31. Soeroso NN, Zain-Hamid $R$, Sinaga BY, Sadewa $A H$, Syafiuddin T, Syahruddin E, et al. The Role of CYP2A6 genetic polymorphism in nicotine dependence and tobacco consumption among bataknese male smokers. Open Access Maced J Med Sci. 2018;6(5):864-6. https://doi.org/10.3889/oamjms.2018.224 PMid:29875862

32. Ariyoshi N, Miyamoto M, Umetsu $\mathrm{Y}$, Kunitoh $\mathrm{H}$, Dosaka-Akita $\mathrm{H}$, Sawamura $\mathrm{Y}$, et al. Cancer Epidemiology and Prevention Biomarkers; 2002. Available from: https://www.cebp.aacrjournals. org/content/11/9/890.long. [Last assecced on 2021 Mar 20].

33. Ma L, Jin G, Yang Y, Pang Y, Wang W, Zhang H, et al. Association between CYP2A13 polymorphisms and lung cancer. Medicine (Baltimore). 2020;99(50):e23289. https://doi.org/10.1097/ md.0000000000023289

PMid:33327254

34. Timofeeva MN, Kropp S, Sauter W, Beckmann L, Rosenberger A, Illig $\mathrm{T}$, et al. CYP450 polymorphisms as risk factors for earlyonset lung cancer: Gender-specific differences. Carcinogenesis. 2009;30(7):1161-9. https://doi.org/10.1093/carcin/bgp102 PMid: 19414505

35. Zhang X, Su T, Zhang QY, Gu J, Caggana M, Li H, Ding X. Genetic polymorphisms of the human CYP2A13 gene: Identification of single-nucleotide polymorphisms and functional characterization of an Arg257Cys variant. J Pharmacol Exp Ther. 2002;302(2):416-23. https://doi.org/10.1124/jpet.302.2.416 PMid:2130698 